\title{
DIFLUORPHOS and SYNPHOS in asymmetric catalysis: Synthetic applications
}

\author{
SEBASTIEN PREVOST, TAHAR AYAD, JEAN-PIERRE GENET, \\ PHANNARATH PHANSAVATH and VIRGINIE RATOVELOMANANA-VIDAL* \\ Institut de Recherche de Chimie Paris, CNRS - Chimie ParisTech, 11 rue Pierre et Marie Curie, 75231 Paris \\ Cedex 05, France \\ e-mail: virginie.vidal@ chimie-paristech.fr
}

MS received 2 July 2013; accepted 7 January 2014

\begin{abstract}
Enantiomerically pure diphosphines play an important role in various homogeneous metalcatalyzed asymmetric reactions. Over the last few years, our group has been involved in the design and synthesis of atropisomeric ligands named SYNPHOS and DIFLUORPHOS with complementary stereoelectronic properties. This paper shows the high catalytic performances of DIFLUORPHOS, SYNPHOS and SYNPHOS analogues for some $\mathrm{C}-\mathrm{H}$ and $\mathrm{C}-\mathrm{C}$ bond forming processes as well as for the synthesis of biorelevant targets.
\end{abstract}

Keywords. Hydrogenation; asymmetric catalysis; total synthesis; atropisomeric phosphines.

\section{Introduction}

Over the last few years, significant research has been directed toward the development of new methods for synthetic efficiency and atom economical processes. ${ }^{1}$ Among them, the potential of transition metal catalysed reactions has been steadily demonstrated, as they provide a direct and selective way towards the synthesis of highly valuable products. We have been engaged in a project dedicated to the development of catalytic methods for the synthesis of biorelevant targets. More specifically, we have been interested in hydrogenation reactions ${ }^{2}$ and $\mathrm{C}-\mathrm{C}$ bond-forming processes which provide important catalytic approaches to fine chemicals. There is no doubt that chiral ligands ${ }^{3}$ are at the heart of any enantioselective homogeneous process. In this context, our contribution to this field is the development of atropisomeric diphosphanes named SYNPHOS $^{4}$ and DIFLUORPHOS ${ }^{5}$ possessing complementary stereoelectronic properties. In particular, the electrodeficient atropisomeric diphosphane DIFLUORPHOS bearing an original stereoelectronic skeleton based on a bi(difluorobenzodioxole) backbone provided excellent enantioselectivities in asymmetric hydrogenation of fluorinated compounds as a result of an atypical combination of a narrow dihedral angle and an unusual $\pi$-acidity. On the other hand, SYNPHOS (bearing a narrow dihedral angle and a stronger basicity) is fully complementary to DIFLUORPHOS in

\footnotetext{
*For correspondence
}

terms of structural features and selectivity. This study focuses, mainly since 2009, on some significant applications of DIFLUORPHOS, SYNPHOS and SYNPHOS analogues (scheme 1), for C-H and C-C bondforming processes and for the synthesis of bioactive molecules.

\section{Carbon-hydrogen bond-forming processes}

\subsection{Ru-catalysed asymmetric hydrogenation of trisubstituted enamides}

The 3-aminochroman moiety is a common structural feature that is present in numerous pharmaceutical drug candidates. ${ }^{6}$ However, only limited progress has been made towards the development of asymmetric synthetic methods for this important structural unit. ${ }^{7}$ In 2011, we reported an atom economical and clean process for the synthesis of 3-aminochroman derivatives through cationic Ru-SYNPHOS-catalysed enantioselective hydrogenation of trisubstituted enamides (scheme 2). ${ }^{8}$ Initial experiments revealed that the nature of the amide moiety and the substitution pattern in the aromatic ring exerted influence on the stereocontrol, while hydrogen pressure and reaction temperature did not significantly affect the stereochemical outcome. For this process, polar solvents tend to provide higher enantioselectivities than non-polar ones, with methanol being the optimum. Under optimized reaction conditions, a wide range of enamides were successfully reduced in moderate to high yields (60-97\%) and ees up 
<smiles>CCCCc1ccc2c(c1-c1c(P)ccc3c1OCCO3)OCCO2</smiles>

(R)-SYNPHOS, $\mathrm{Ar}=\mathrm{C}_{6} \mathrm{H}_{5}$

(R)-3,5-diMe-SYNPHOS, $\mathrm{Ar}=3,5$-diMe- $\mathrm{C}_{6} \mathrm{H}_{3}$

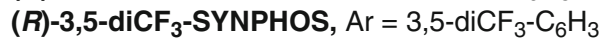

(R)-4- $\mathrm{CF}_{3}-\mathrm{SYNPHOS}, \mathrm{Ar}=4-\mathrm{CF}_{3}-\mathrm{C}_{6} \mathrm{H}_{4}$<smiles>FC(F)(F)Oc1ccc(-c2ccccc2)c(-c2c(-c3ccccc3)ccc3c2OC(F)(F)O3)c1</smiles>

(R)-DIFLUORPHOS

Scheme 1. DIFLUORPHOS, SYNPHOS and SYNPHOS analogues.

to $96 \%$ as illustrated by some representative examples depicted in scheme 2 .

\subsection{Ir-catalysed asymmetric hydrogenation of quinoline derivatives}

Transition-metal catalysed asymmetric hydrogenation of readily available heteroaromatic derivatives provided a straightforward route to enantiomerically enriched nitrogen-containing scaffolds which are biorelevant targets in pharmaceutical industry. ${ }^{9}$ Zhou et al. described in 2003 the first iridium-catalysed asymmetric hydrogenation of quinoline derivatives using $(R)$ -
MeO-BIPHEP with excellent yields up to $94 \%$ and enantioselectivities up to $96 \% .{ }^{10}$ Since this pioneering study, several efficient processes have been reported using electron-deficient or electron-rich atropisomeric ligands. ${ }^{11-17}$ Hydrogenation reactions have been usually performed by mixing $[\operatorname{Ir}(\mathrm{COD}) \mathrm{Cl}]_{2}$ and the appropriate diphosphine ligand or by using $\operatorname{Ir}(\mathrm{III})$ complexes $\left\{[\mathrm{IrH} \text { (diphosphine) }]_{2}(\mu-\mathrm{X})_{3}\right\}^{+} \mathrm{X}^{-}(\mathrm{X}=\mathrm{Br}, \mathrm{Cl}, \mathrm{I})$ as shown in scheme $3 .{ }^{18}$

Zhou et al. reported strategies based on substrate activation by chloroformates using $\operatorname{Ir} /(S)$ SEGPHOS $/ \mathrm{Li}_{2} \mathrm{CO}_{3} / \mathrm{ClCO}_{2} \mathrm{Bn} / \mathrm{THF}$ catalyst system to promote the hydrogenation of 2-alkylquinoline derivatives. ${ }^{10 \mathrm{~b}}$ In collaboration with Mashima and

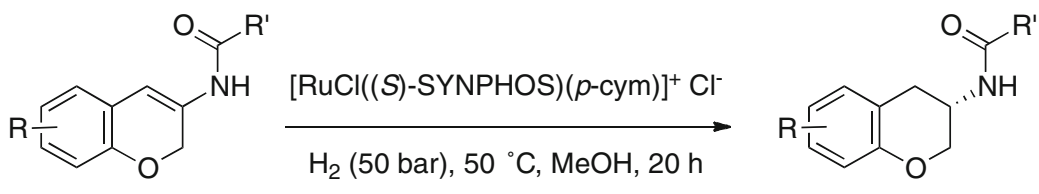

$\mathrm{R}=\mathrm{Me}, \mathrm{MeO}, \mathrm{F}, \mathrm{Cl}, \mathrm{Br}$

$\mathrm{R}^{\prime}=\mathrm{Me}, \mathrm{Et}, \mathrm{Pr}, t-\mathrm{Bu}, \mathrm{Ph}, \mathrm{OBn}$

up to $97 \%$ yield up to $96 \%$ ee

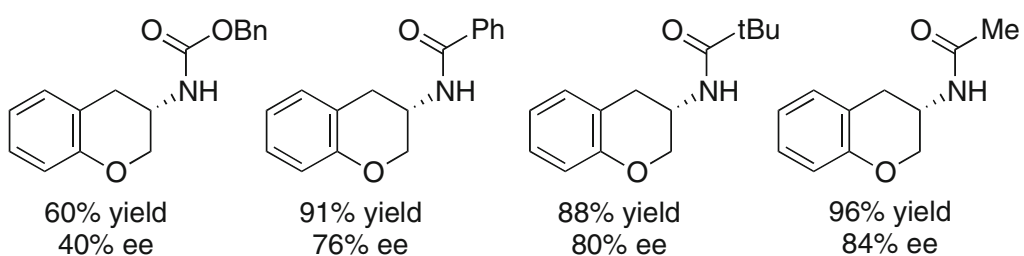<smiles>COc1ccc2c(c1)OC[C@@H](NC(C)=O)C2</smiles>

Note: $p$-cym $=p$-cymene

Scheme 2. Ru-catalysed enantioselective hydrogenation of trisubstituted enamides. 


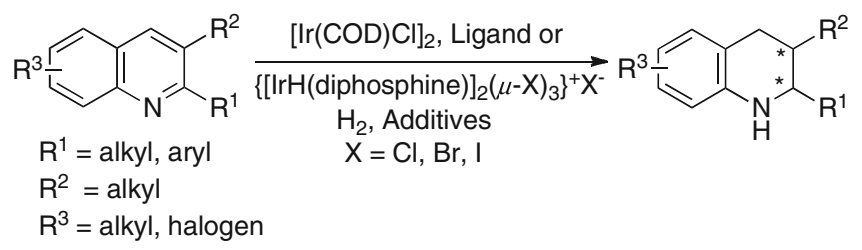

Note: $\mathrm{COD}=1,5$-cyclooctadiene

Scheme 3. General Ir-catalysed hydrogenation of quinolines.

Ohshima, our group showed that the hydrogenation reaction could be efficiently performed on 2-alkyl- and 2-arylquinolinium chlorhydrate or bromhydrate derivatives using $\left\{[\operatorname{IrH}((S) \text {-diphosphine })]_{2}(\mu-\mathrm{Y})_{3}\right\}^{+} \mathrm{Y}^{-}(\mathrm{Y}=$ $\mathrm{Cl}, \mathrm{Br}$ ) catalysts incorporating atropisomeric diphosphines such as BINAP, tol-BINAP, SYNPHOS, SEGPHOS, DTBM-SEGPHOS and DIFLUORPHOS. The corresponding tetrahydroquinolines were synthesized with excellent conversions and enantioselectivities as high as $95 \%$ with better enantiofacial discrimination reached with para and meta-substituted $\mathrm{HCl}$ or $\mathrm{HBr}$ arylquinolinium salts compared to the corresponding ortho-substituted derivatives. ${ }^{19}$ Some representative examples are depicted in scheme 4.

These results demonstrated the unexpected performance of chloro and bromo-iridium dinuclear Ir-DIFLUORPHOS catalysts compared to the corresponding iodo-iridium complexes.
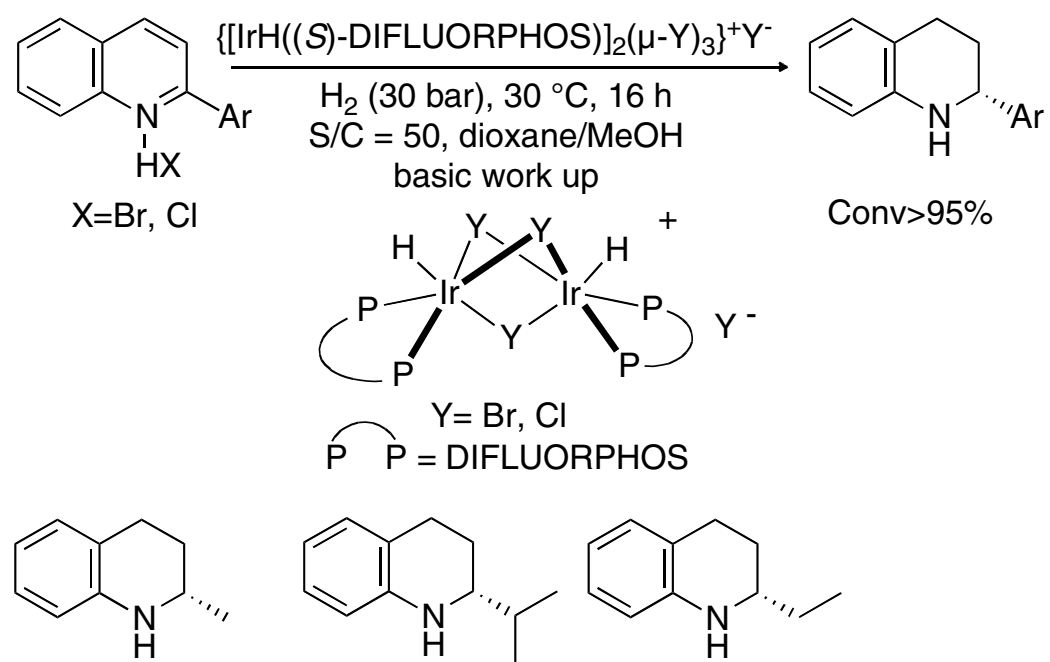<smiles>CC(C)[C@H]1CCc2ccccc2N1</smiles><smiles>CC[C@@H]1CCc2ccccc2N1</smiles>

$94 \%$ ee $95 \%$ ee<smiles>Pc1ccc([C@@H]2CCc3ccccc3N2)cc1</smiles><smiles>Cc1cccc([C@@H]2CCc3ccccc3N2)c1</smiles>

$93 \%$ ee

$\mathrm{R}=\mathrm{Me}$ or $\mathrm{OMe}, 90 \%$ ee $92 \%$ ee<smiles>Cc1ccccc1[C@@H]1CCc2ccccc2N1</smiles>
$88 \%$ ee<smiles>COc1cccc([C@@H]2CCc3ccccc3N2)c1</smiles>

Scheme 4. Ir-catalysed asymmetric hydrogenation of quinolinium salts. 


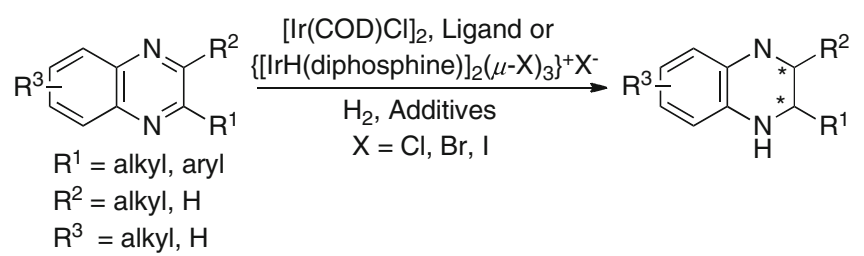

Scheme 5. Ir-catalysed asymmetric hydrogenation of quinoxalines.

\subsection{Ir-catalysed asymmetric hydrogenation of quinoxaline derivatives}

Enantiomerically enriched tetrahydroquinoxaline derivatives are key building blocks for a range of promising targets for medicinal chemistry studies. ${ }^{20}$ As previously mentioned for quinoline derivatives, hydrogenation of quinoxalines to access the corresponding tetrahydroquinoxalines can be carried out by mixing $[\operatorname{Ir}(\mathrm{COD}) \mathrm{Cl}]_{2}$ and the chiral ligand or by using preformed cationic dinuclear triply halogen-bridged iridium complexes $\left\{[\operatorname{Ir}(\mathrm{H})((S) \text {-diphosphine })]_{2}(\mu-\mathrm{X})_{3}\right\} \mathrm{X}$ (scheme 5).

Since the pioneering report by Murata in $1987,{ }^{21}$ most of the hydrogenations have been limited to 2-methylquinoxaline. ${ }^{22}$ Electronically rich or deficient monodentate or bidentate phosphines, ${ }^{23-27}$ were used in the asymmetric hydrogenation of 2methylquinoxaline. We demonstrated in 2010 that the cationic dinuclear triply halogen-bridged iridium complex $\left.\{[\operatorname{IrH}(S) \text {-DIFLUORPHOS })]_{2}(\mu-\mathrm{Cl})_{3}\right\}^{+} \mathrm{Cl}^{-}$ enabled the hydrogenation of quinoxaline derivatives with no substrate activation allowing the hydrogenation reaction of a series of 2-alkyl and challenging 2-aryl substituted quinoxalines under mild conditions with good yields up to $99 \%$ and high levels of enantioselectivities up to $95 \%$ (scheme 6). ${ }^{27}$ The iridium(III)DIFLUORPHOS catalytic system provided an efficient access to valuable building blocks of synthetic interest. A crucial role of amines was highlighted in 2012 by Mashima et al. ${ }^{28}$

\subsection{Ir-catalysed asymmetric hydrogenation of isoquinoline derivatives}

Isoquinoline derivatives, widely present in plants and several tissues in mammalian alkaloids, play an important role in the field of medicinal chemistry due to their remarkable pharmacological potential. ${ }^{29}$ Asymmetric hydrogenation of 1-substituted-3,4-dihy-
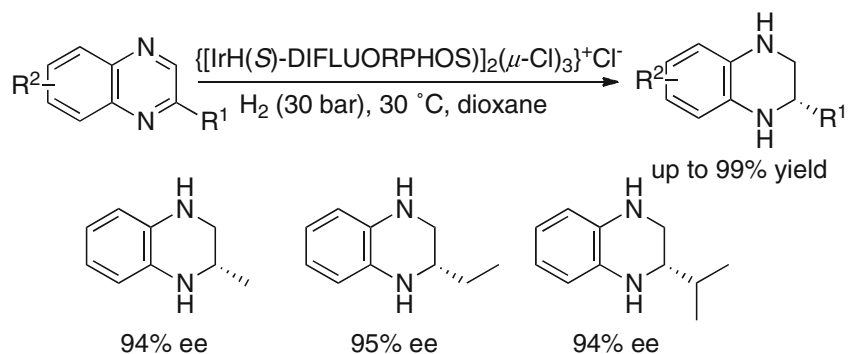<smiles>O=[N+]1Nc2ccccc2NC1CCc1ccccc1</smiles><smiles>CCCCC1CNc2cc(C)c(C)cc2N1</smiles><smiles>Cc1ccccc1C1NCc2ccccc2N1</smiles><smiles>Clc1ccc(C2CNc3ccccc3N2)cc1</smiles><smiles>COc1ccc(C2CNc3ccccc3N2)cc1</smiles><smiles>O=[N+]([O-])c1ccc(C2CNc3ccccc3N2)cc1</smiles>

Scheme 6. Ir-catalysed asymmetric hydrogenation of quinoxaline derivatives. 


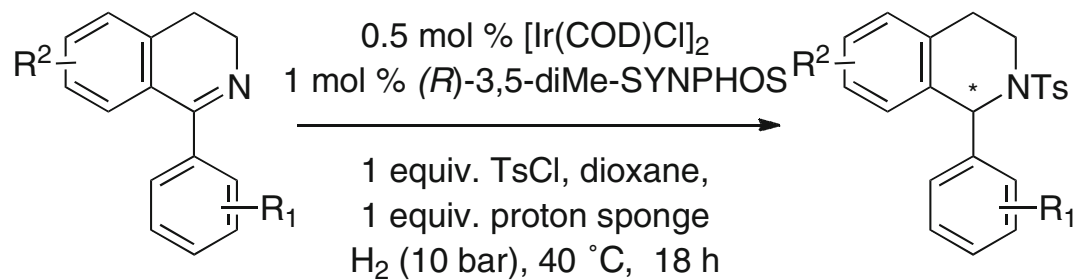

$$
\begin{aligned}
& \mathrm{R}^{2}=\mathrm{Me}, \mathrm{MeO} \\
& \mathrm{R}^{1}=\mathrm{Me}, \mathrm{MeO}, \mathrm{F}, \mathrm{Cl}, \mathrm{Br}
\end{aligned}
$$<smiles>Cc1ccc(P(c2ccc3c(c2-c2cccc(C)c2)OCCO3)c2ccc3c(c2-c2c(P(c4cc(C)cc(C)c4)c4cc(C)cc(C)c4)ccc4c2OCCO4)OCCO3)cc1</smiles>

up to $95 \%$ yield up to $94 \%$ ee

(R)-3,5-diMe-SYNPHOS<smiles></smiles>

$\mathrm{MeO}$<smiles>Cc1ccc2c(c1)CCN([13CH3])[C@H]2c1ccccc1</smiles>

$80 \%$ yield

$88 \%$ ee $(99 \%)$<smiles>COc1ccc2c(c1)[C@@H](c1ccccc1)N([13CH3])CC2</smiles><smiles>COc1ccccc1[C@@H]1c2ccccc2CCN1C(F)(F)F</smiles><smiles>COc1cc2c(cc1OC)[C@H](c1ccccc1)N([13CH3])CC2</smiles>

$77 \%$ yield $88 \%$ ee $(99 \%)$<smiles>COc1cc2c(cc1OC)[C@@H](c1ccc(C)cc1)N([13CH3])CC2</smiles>

Scheme 7. Ir-catalysed asymmetric hydrogenation of isoquinoline derivatives.

droisoquinoline derivatives (DHIQs) provides a practical, convenient and atom-economically efficient route to 1-substituted-tetrahydroisoquinoline (THIQ) scaffolds. To date, only few approaches are based on catalytic asymmetric reactions. ${ }^{30}$ Since the pioneering studies of Buchwald et al. ${ }^{31}$ and Noyori et al., ${ }^{32}$ only a few efficient catalytic systems have been described to access 1-alkyl-THIQs in high enantioselectivity; whereas 1-aryl-THIQs were prepared with low to moderate selectivity. ${ }^{33}$ Until now, only two reports of catalytic enantioselective reduction of 1-aryl-substituted-3,4-dihydroisoquinolines have been 

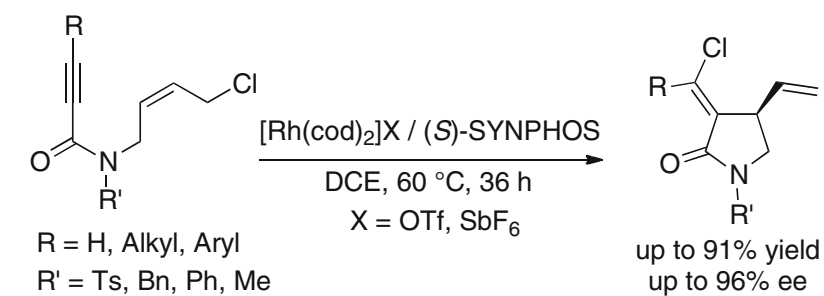

up to $96 \%$ ee<smiles>C=CC1CN(Cc2ccccc2)C(=O)C1=C(C)Cl</smiles><smiles>C=CC1CN(c2ccccc2)C(=O)C1=C(C)Cl</smiles><smiles>C=CC1CN(C)C(=O)C1=C(C)Cl</smiles><smiles>C=C[C@H]1CN([Te])C(=O)C1=C(C)Cl</smiles>

$48 \%$ yield $51 \%$ yield $72 \%$ ee

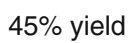
$77 \%$ ee $91 \%$ yield<smiles>C=C[C@H]1CN(CBr)C(=O)C1=C(Cl)Cl</smiles>

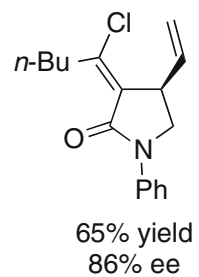
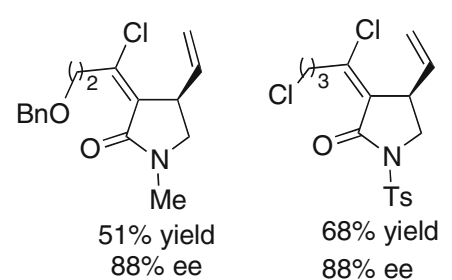

Scheme 8. Synthesis of $\alpha$-chloromethylene- $\gamma$-butyrolactams.

reported. ${ }^{33 \mathrm{k}}$ We demonstrated that $[\operatorname{Ir}(\mathrm{COD}) \mathrm{Cl}]_{2} /(R)$ 3,5-diMe-SYNPHOS catalyst is highly efficient for the enantioselecive hydrogenation of challenging 1aryl-3,4-dihydroisoquinolines under mild reaction conditions. This method provides an atom economical and attractive route to pharmaceutically relevant enantiomerically enriched 1-aryl-THIQ compounds in high yields up to $95 \%$ and excellent enantioselectivities up to $>99 \%$, after a single crystallization (scheme 7). ${ }^{34}$

Mashima et al. reported in 2013 the first efficient asymmetric hydrogenation of 1- and 3-substituted isoquinolinium salts using the new class of cationic dinuclear triply halogen-bridged iridium complexes $\left\{[\operatorname{Ir}(\mathrm{H})((S) \text {-diphosphine })]_{2}(\mu-\mathrm{X})_{3}\right\} \mathrm{X}^{35}$

\section{Carbon-carbon bond-forming processes}

\subsection{Rhodium-catalysed asymmetric}

cycloisomerization of $N$-tethered 1,6-enynes

with an intramolecular halogen shift

Metal-catalysed cycloisomerization of 1,n-enynes is one of the most efficient methods for the synthesis of a variety of carbocyclic and heterocyclic compounds that contribute to sustainable development and atom economy concepts. ${ }^{36}$ In 2012, Zhang, RatovelomananaVidal and co-workers reported an efficient rhodiumcatalysed enantioselective cycloisomerization of $\mathrm{N}$ tethered 1,6-enynes with an intramolecular halogen shift leading to the corresponding $\alpha$-chloromethylene$\gamma$-butyrolactams (scheme 8). ${ }^{37} \mathrm{~A}$ number of atropisomeric diphosphine ligands including BINAP, SEGPHOS, DIFLUORPHOS, SYNPHOS and SUNPHOS family of ligands were screened for these transformations using various cationic rhodium complexes. As a result of these investigations, it was demonstrated that the stereochemical outcome of the reaction is strongly influenced by the nature of the ligands employed. The SYNPHOS ligand used in combination with either $\left[\mathrm{Rh}(\operatorname{cod})_{2}\right]^{+} \mathrm{SbF}_{6}^{-}$or $\left[\mathrm{Rh}(\operatorname{cod})_{2}\right]^{+} \mathrm{OTf}^{-}$as rhodium sources turned out to be the ligand of choice for this process, giving the desired cyclized products in moderate to good yields (45-91\%) and with enantioselectivities ranging from $67 \%$ to $96 \%$. During this screening phase, it was also established that both reactivity and enantioselectivity were influenced by the nature of the $N$-protecting group, the $N$-tosyl derivatives providing higher catalytic activity. As illustrated in scheme 8 , both aryl and alkyl substituents are tolerated on the alkyne moiety.

\subsection{Rh-catalysed asymmetric conjugate 1,4-addition of arylboronic acids to activated alkenes}

Since the initial breakthrough reported by Hayashi, Miyaura et al. in $1998,{ }^{38}$ the Rh-catalysed enantioselective conjugate 1,4-addition of organoboron reagents to activated alkenes is arguably one of the most 
powerful and highly stereoselective synthetic methods for carbon-carbon bond-forming processes. ${ }^{39}$ Consequently, a large number of catalytic systems have been developed for this useful reaction. However, with the exception of chiral dienes, ${ }^{40}$ most of them operate at elevated temperature to achieve high catalytic activity. In 2009, Sakai and co-workers ${ }^{41}$ showed for the first time that the use of electron-poor chiral atropisomeric diphosphine ligands could significantly improve the catalytic activity for Rh-catalysed 1,4-addition of arylboronic acids at room temperature. Inspired by this work, we reported that rhodium complexes bearing new fluorinated 3,5-diCF $-\mathrm{SYNPHOS}$ and $p-\mathrm{CF}_{3}-$ SYNPHOS ligands developed by our group, were also highly effective catalysts for this transformation. Initial investigations were conducted at $20^{\circ} \mathrm{C}$ using $1.5 \mathrm{~mol} \%$ of catalyst in the presence of $\mathrm{KOH}$ in toluene $/ \mathrm{H}_{2} \mathrm{O}$ (9/1) for $18 \mathrm{~h}$ with cyclohexenone as a model substrate (scheme 9). It was found that a wide range of arylboronic acids were tolerated in this reaction giving the corresponding Michael adducts in good to excellent yields and with excellent enantioselectivity. It should be noted that the use of sterically more hindered arylboronic acids such as 2-tolylboronic acid and 1-naphthylboronic acid gave slightly lower enantioselectivity, probably due to increased steric hindrance. As highlighted in scheme 9, both cyclic and acyclic $\alpha, \beta$ unsaturated ketones and lactones were found to be suitable substrates for this process. Under optimized reaction conditions, the corresponding cyclic and acyclic 1,4-adducts were obtained in moderate to excellent yields (62-96\%) and with excellent enantioselectivities (93-99\%).

Remarkably, the above mentioned Rh- $(R)-3,5-\mathrm{diCF}_{3}-$ SYNPHOS catalyst system proved to be also highly efficient for the Rh-catalysed asymmetric conjugate 1,4-addition of arylboronic acids to maleimide derivatives, which are one of the most tricky substrates and for which only a few efficient catalytic systems have been reported (scheme 10). ${ }^{42}$ After intensive experiments, optimized reaction conditions were established using $3 \mathrm{~mol} \%$ of $\mathrm{Rh}-(R)-3,5-\mathrm{diCF}_{3}-\mathrm{SYNPHOS}$ complex as a catalyst in toluene/ $\mathrm{H}_{2} \mathrm{O}(9 / 1)$ in combination with 0.5 equiv. of $\mathrm{KOH}$ as base, at $30^{\circ} \mathrm{C}$ for $3 \mathrm{~h}$. From this screening, it was found that the nature of the $N$-protecting groups of the maleimide had a dramatic impact on the stereochemical outcome of the reaction, the $N$-methyl maleimide being the substrate of choice providing the best results in terms of both yield and selectivity. As illustrated by some representative examples depicted in scheme 10, the reaction conducted with a wide variety of arylboronic acids bearing both electron-withdrawing and electron-donating substituents resulted in the formation of various synthetically and biologically important chiral 3-aryl substituted succinimide derivatives, in high yields (75-90\%) and good to excellent enantiomeric excesses (80-94\% ee). Interestingly, all the 1,4-addition products could be easily upgraded up to $94-99 \%$ ee, after a single crystallization.

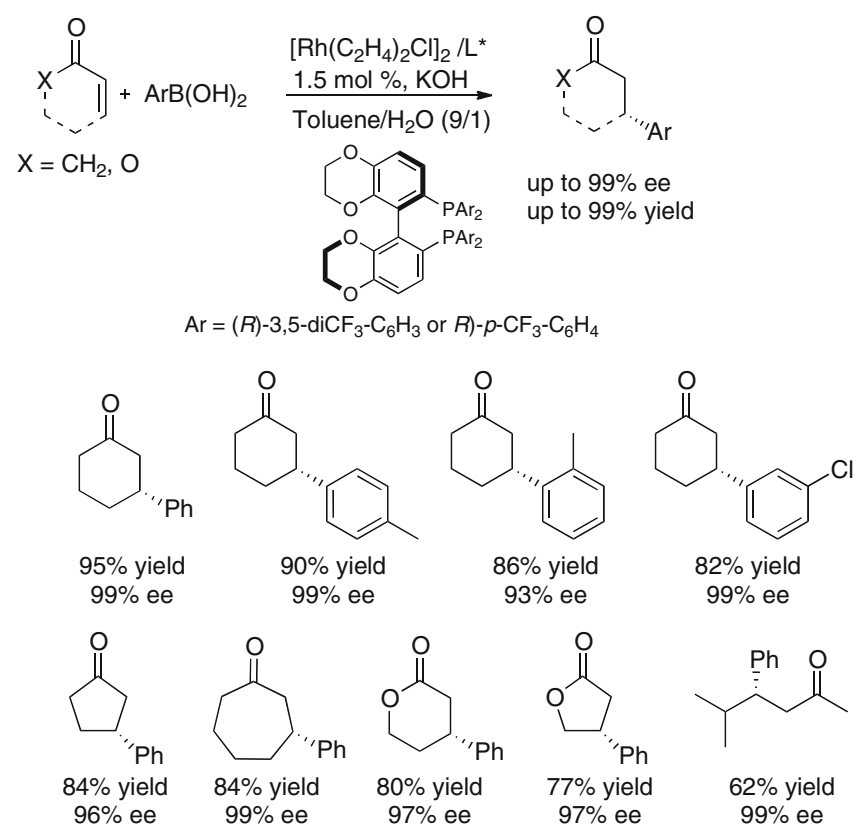

Scheme 9. Rh-catalysed conjugate addition of arylboronic acids to activated alkenes. 

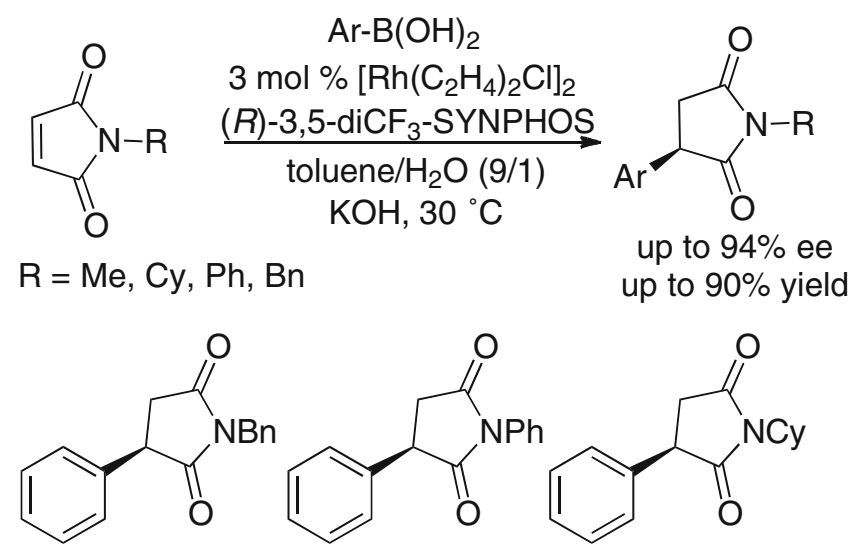<smiles>CCCNC1C(=O)C[C@H](c2ccccc2)C1=O</smiles><smiles>O=C1C[C@H](c2ccccc2)C(=O)N1[AlH2]</smiles>

$89 \%$ yield

$48 \%$ ee

$79 \%$ yield

$85 \%$ yield

$67 \%$ ee

$80 \%$ ee<smiles>COc1ccc([C@H]2CC(=O)N(C)C2=O)cc1</smiles><smiles>CN1C(=O)C[C@H](c2ccc(Cl)cc2)C1=O</smiles>

$80 \%$ yield

$87 \%$ ee<smiles>CCCCC(=O)OCc1cccc(F)c1</smiles>

Scheme 10. Rh-catalysed conjugate addition of arylboronic acids to maleimides.

\subsection{Rh-catalysed asymmetric intramolecular Pauson-Khand reaction}

Since its discovery in the early $1970 \mathrm{~s},{ }^{43}$ the formal $[2+2+1]$ cycloaddition reaction of an alkyne and an alkene in the presence of carbon monoxide to produce a cyclopentenone, known as the Pauson-Khand (PK) reaction, has been recognized as one of the best methods in organic synthesis to produce cyclopentenone derivatives or cyclopentane-containing natural products. ${ }^{44}$ In 2007, we have reported an efficient intramolecular enantioselective PK reaction of $O$ - and $\mathrm{N}$-tethered 1,6-enynes catalysed by cationic $\mathrm{Rh}$ catalysts generated in situ from $\left[\mathrm{Rh}(\mathrm{CO})_{2} \mathrm{Cl}\right]_{2}$ in the presence of AgOTf as chloride scavenger and various chiral diphosphines including SYNPHOS, DIFLUORPHOS and BINAP family of ligands (scheme 11). It was found during this ligand screening that product yield and enantioselectivity of the reaction were greatly influenced by both the stereoelectronic properties of the ligands and the electronic density of the alkyne substrates. SYNPHOS and DIFLUORPHOS, which possess a narrower dihedral angle than BINAP type ligands, give improved catalytic activity for most substrates. As highlighted in scheme 11, under optimized reaction conditions, various 1,6-enynes bearing both alkyl and aryl substituents on the alkyne moiety react smoothly at $80^{\circ} \mathrm{C}$ in THF under a low pressure of $\mathrm{CO}$ (1 atm) to give the corresponding bicyclic cyclopentenones in moderate to good yields and moderate to excellent enantioselectivities.

\subsection{Rh-catalysed asymmetric desymmetrization through Pauson-Khand reaction}

Transition metal-catalysed asymmetric desymmetrization is an efficient and powerful tool for synthesizing optically active compounds. This strategy stands out as 


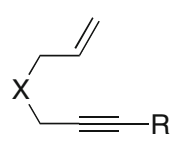

$\mathrm{X}=\mathrm{O}, \mathrm{TsN}$

$\mathrm{R}=$ Aryl, Alkyl

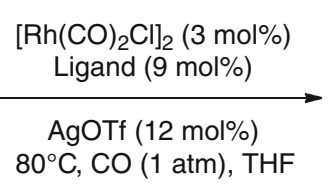

$80^{\circ} \mathrm{C}, \mathrm{CO}$ (1 atm), THF<smiles>[X]CC1=C([R])C(=O)C[C@H]1C</smiles>

up to $98 \%$ yield up to $98 \%$ ee
(S)-SYNPHOS<smiles>CC1=C2COC[C@H]2CC1=O</smiles>

$42 \%$ yield $98 \%$ ee

(S)-DIFLUORPHOS $38 \%$ yield $94 \%$ ee<smiles>COc1ccc(C2=C3COC[C@H]3CC2=O)cc1</smiles>

$56 \%$ yield $89 \%$ ee $70 \%$ yield $91 \%$ ee<smiles>O=C1C[C@H]2COCC2=C1c1ccccc1</smiles>

$75 \%$ yield $85 \%$ ee

$81 \%$ yield $87 \%$ ee<smiles>O=C1C[C@H]2COCC2=C1c1ccc(C(F)(F)F)cc1</smiles>

$82 \%$ yield $85 \%$ ee $80 \%$ yield $90 \%$ ee

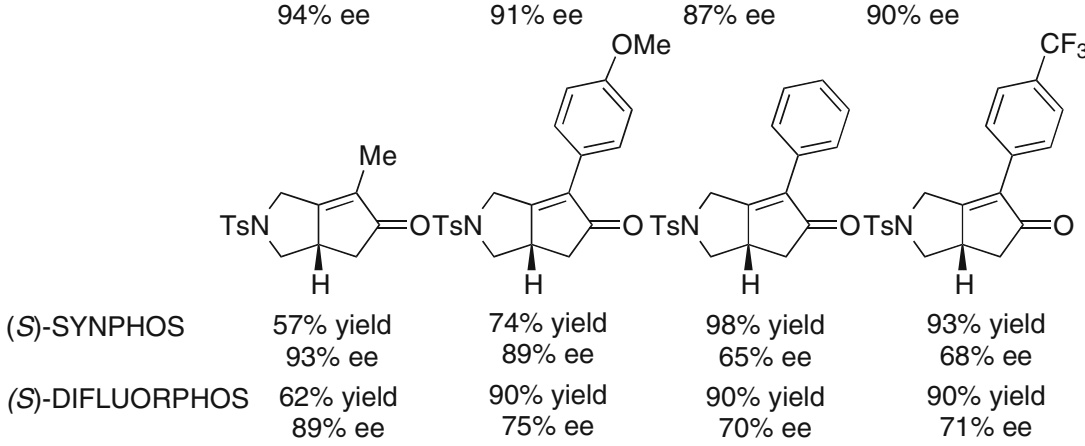

Scheme 11. Rh-catalysed asymmetric intramolecular Pauson-Khand reaction.

a synthetically practical method because chiral compounds bearing one or multiple chiral centres can be created in a controlled fashion, through differentiation of two prochiral functional groups on readily prepared meso or achiral substrates. ${ }^{45}$ In 2007 , we reported an efficient enantioselective synthesis of biologically relevant cyclopentenone derivatives via a one-pot, twosteps sequence involving a Pauson-Khand reaction followed by acidic hydrolysis of the resulting bicyclic compounds (scheme 12). ${ }^{46}$ In this transformation, a wide variety of bisallenyl propargyl acetals reacted smoothly through a PK reaction to give the cyclized compounds using a neutral Rh(I)-SYNPHOS catalyst prepared in situ by mixing $3 \mathrm{~mol} \%$ of $[\mathrm{Rh}(\mathrm{cod}) \mathrm{Cl}]_{2}$ and $9 \mathrm{~mol} \%$ of SYNPHOS. Subsequent acidic hydrolysis of the bicyclic compounds afforded the desired chiral cyclopentenones in good yields $(77-84 \%)$ and moderate to excellent enantiomeric excesses ranging

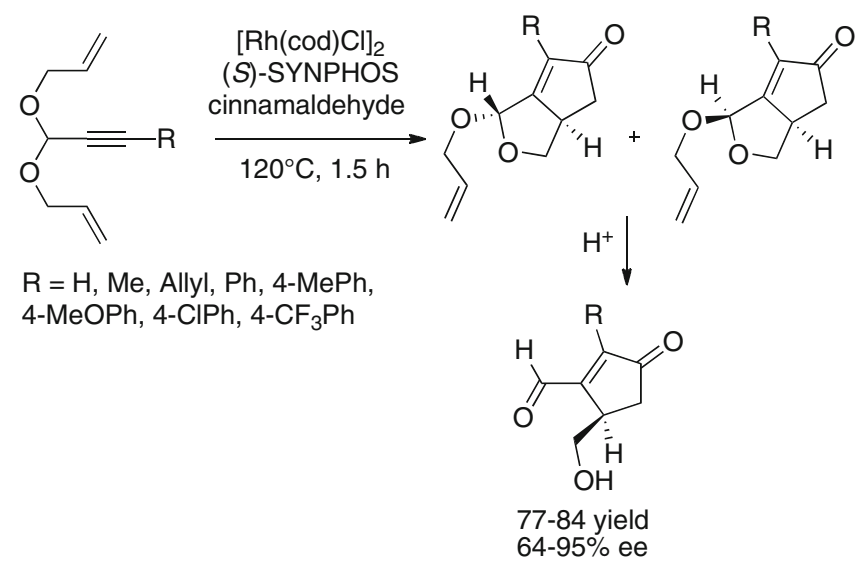

Scheme 12. Rh-catalysed asymmetric desymmetrization through Pauson-Khand reaction. 


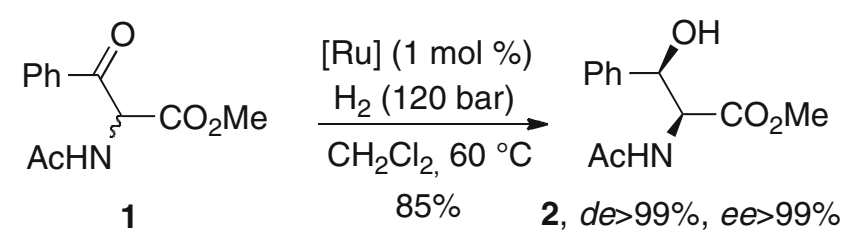

$[\mathrm{Ru}]=\left[\{\mathrm{RuCl}((R)-\mathrm{SYNPHOS})\}_{2}(\mu-\mathrm{Cl})_{3}\right]^{-}\left[\mathrm{NH}_{2} \mathrm{Me}_{2}\right]^{+}$

1. $6 \mathrm{~N}-\mathrm{HCl}$, reflux, $91 \%$

2. $(\mathrm{Boc})_{2} \mathrm{O}, \mathrm{NaHCO}_{3}$, dioxane $/ \mathrm{H}_{2} \mathrm{O}$

3. $\mathrm{BnBr}, \mathrm{Cs}_{2} \mathrm{CO}_{3}$, DMF

4. $\mathrm{TFA} / \mathrm{CH}_{2} \mathrm{Cl}_{2}(1: 3)$, then $\mathrm{Et}_{3} \mathrm{~N}, \mathrm{DMF}$ $77 \%$ (4 steps)<smiles>NC(C(=O)Oc1ccccc1)C(O)c1ccccc1</smiles>

Pser fragment 3

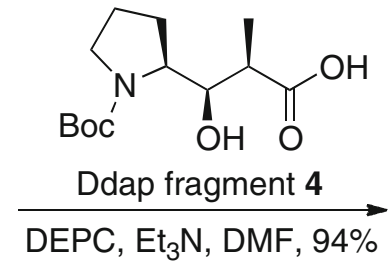<smiles>CC(C(=O)N[C@H](C(=O)OCc1ccccc1)C(O)c1ccccc1)[C@H](O)[C@H](O)C1CCCN1C(=O)OC(C)(C)C</smiles>

1. $2 \mathrm{~N}$ - $\mathrm{HCl} . \mathrm{Et}_{2} \mathrm{O} / \mathrm{CH}_{2} \mathrm{Cl}_{2}(1: 1)$ then $\mathrm{Et}_{3} \mathrm{~N}$, DMF

2.<smiles>CCC(C)[C@H](NC(=O)OCc1ccccc1)[C@@H](CC(=O)O)OC</smiles>

Ddil fragment 6

DEPC, $\mathrm{Et}_{3} \mathrm{~N}, \mathrm{DMF}$<smiles>CCC(C)C(N)C(CC(=O)N1CCC[C@H]1[C@H](O)[C@@H](C)C(=O)NC(C(=O)OCc1ccccc1)C(O)c1ccccc1)OC</smiles>

3. $2 \mathrm{~N}-\mathrm{HCl}$. $\mathrm{Et}_{2} \mathrm{O} / \mathrm{CH}_{2} \mathrm{Cl}_{2}(1: 1)$

then $\mathrm{NaHCO}_{3}, 89 \%$ (3 steps)

1. $\mathrm{N}$-Boc-D-Ser-lle-OH, $\mathrm{HOBt} / \mathrm{H}_{2} \mathrm{O}$ DCC, DME

2. $2 \mathrm{~N}-\mathrm{HCl}$. $\mathrm{Et}_{2} \mathrm{O} / \mathrm{CH}_{2} \mathrm{Cl}_{2}(1: 1)$ then $\mathrm{NaHCO}_{3}$

3. $(\mathrm{CbzNH})_{2} \mathrm{C}=\mathrm{NTf}, \mathrm{Et}_{3} \mathrm{~N}, \mathrm{CH}_{2} \mathrm{Cl}_{2}$

4. $20 \% \mathrm{Pd}(\mathrm{OH})_{2} / \mathrm{C}, \mathrm{H}_{2} \mathrm{MeOH}$

5. $0.1 \%$ TFA, $\mathrm{MeOH}, 70 \%$ (5 steps)

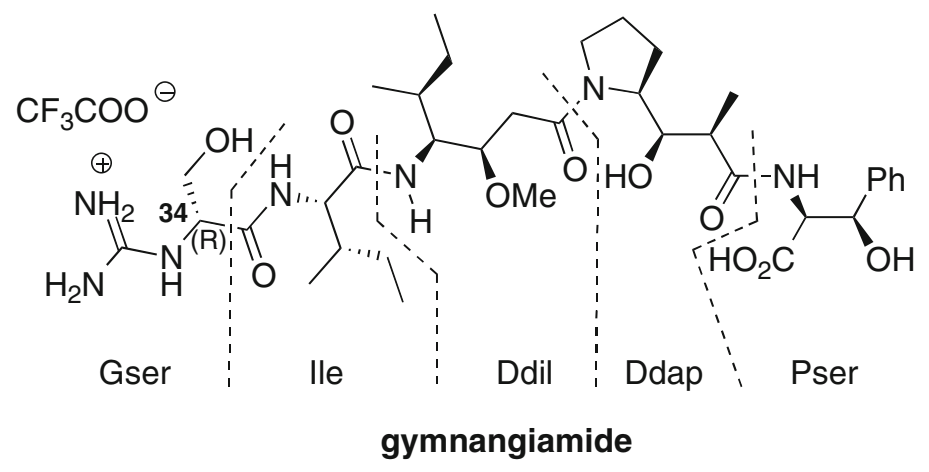

Scheme 13. Total synthesis of gymnangiamide. 
from $64 \%$ to $95 \%$. It should be noted that cinnamaldehyde not only serves as a solvent but also as a source of carbon monoxide by in situ $\mathrm{Rh}(\mathrm{I})$-catalysed decarbonylation.

\section{Synthetic applications}

As part as our ongoing projects directed toward the synthesis of relevant biologically active molecules, we have successfully used both SYNPHOS and DIFLUORPHOS ligands in the hydrogenation of functionalized ketones for the total synthesis of gymnangiamide, symbioramide, taxotere ${ }^{\circledR}$ and SR58611A.

\subsection{Synthesis of gymnangiamide}

Gymnangiamide $^{47}$ is a cytotoxic pentapeptide isolated in 2004 from the marine hydroid Gymnangium regae Jaderholm, which contains three non-standard amino acid residues, namely $N$-desmethyl-Dolaisoleucine (Ddil), $O$-desmethyl-Dolaproine (Ddap) and $\alpha$-guanidino- $L$-serine (Gser) as well as $(2 S, 3 S)$-isoleucine (Ile) and $(2 S, 3 R)$-phenylserine (Pser). We reported a total synthesis of gymnangiamide relying on $\mathrm{Ru}-$ SYNPHOS-mediated asymmetric hydrogenation of $\alpha$ substituted $\beta$-ketoesters through dynamic kinetic resolution for the preparation of the non-proteinogenic chiral amino acids Pser 3 and Ddap 4 (scheme 13). The syn $\alpha$-amino $\beta$-hydroxyester and $\alpha$-methyl $\beta$-hydroxy<smiles>COC(=O)C(N)C(=O)c1ccccc1</smiles>

(土)-8

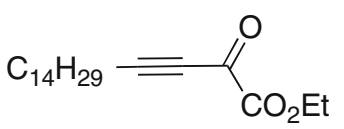

11

1. $\mathrm{H}_{2}$ (12 bar), $\mathrm{CH}_{2} \mathrm{Cl}_{2} / \mathrm{MeOH}$, $50^{\circ} \mathrm{C}, 24 \mathrm{~h}$ $\left[\mathrm{Ru}((R)-\mathrm{SYNPHOS}) \mathrm{Br}_{2}\right]$ (2 $\mathrm{mol} \%)$

2. $\mathrm{Et}_{3} \mathrm{~N}, \mathrm{Et}_{2} \mathrm{O} / \mathrm{MeOH}, \mathrm{rt}$ $66 \%$ (2 steps)<smiles>COC(=O)[C@H](N)[C@H](O)c1ccccc1</smiles>

$9(96 \%$ ee, $95 \%$ de)

1. $\mathrm{LiAlH}_{4}, \mathrm{THF}, \mathrm{rt}$

2. DMP, PPTS, $\mathrm{CHCl}_{3}, \Delta$

$\checkmark 62 \%$ (2 steps)

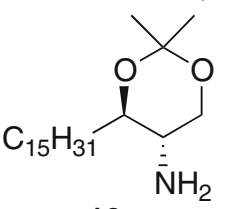

10<smiles>CCCCCCCCC(O)C(OCC)OCC</smiles>

$12(83 \%, 97 \%$ ee)

1. $\mathrm{LiAlH}_{4}$ THF

2. TBSCI, DMAP, DIPEA

3. TBDPSCI, Imid, DMF

4. $\mathrm{AcOH}, \mathrm{THF} / \mathrm{H}_{2} \mathrm{O}$

5. Jones' reagent $24 \%$ (5 steps)

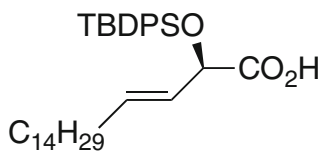

13

1. HATU, DIPEA, $\mathrm{CH}_{2} \mathrm{Cl}_{2}, 0^{\circ} \mathrm{C}$

2. PTSA, $\mathrm{CH}_{2} \mathrm{Cl}_{2} \mathrm{MeOH}$

3. TBAF, THF, 35\% (3 steps)

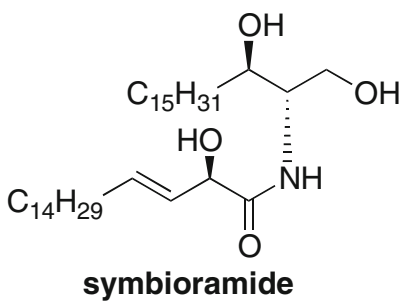

Scheme 14. Total synthesis of symbioramide. 
<smiles>COC(=O)C(Cl)C(=O)c1ccccc1</smiles>

$( \pm)-14$

$\left[\mathrm{Ru}\{(R)\right.$-DIFLUORPHOS $\left.\} \mathrm{Br}_{2}\right] \mathrm{S} / \mathrm{C}=200$

$\mathrm{H}_{2}$ (60 bar), $\mathrm{CH}_{2} \mathrm{Cl}_{2}, 50^{\circ} \mathrm{C}, 68 \mathrm{~h}$ $55 \%, 96 \%$ de, $92 \%$ ee<smiles>COC(=O)[C@H](Cl)[C@H](O)c1ccccc1</smiles>

$(2 R, 3 R)-15$

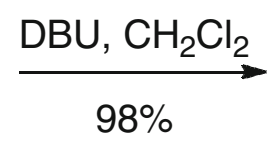

trans/cis: 99/1, 93\% ee

1. $\mathrm{NaN}_{3}, \mathrm{NH}_{4} \mathrm{Cl}$ acetone $/ \mathrm{H}_{2} \mathrm{O}, \Delta$

2. $\mathrm{H}_{2}$ (1 atm), $\mathrm{Pd} / \mathrm{C}, \mathrm{Boc}_{2} \mathrm{O}$ AcOEt, 66\% (2 steps)<smiles>COC(=O)[C@H](O)[C@H](N=C(O)c1ccccc1)c1ccccc1</smiles>

17

$\underset{\text { 1. } p \text { - } \mathrm{MeOPhCH}(\mathrm{OMe})_{2}, \mathrm{PPTS}, \Delta}{\mathrm{K}_{2} \mathrm{CO}_{3}, \mathrm{MeOH} / \mathrm{H}_{2} \mathrm{O}, 62 \% \text { (2 steps) }}$

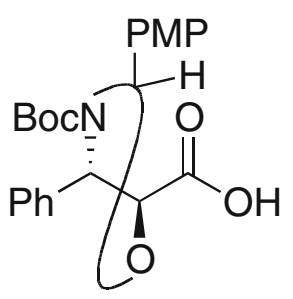

1. DCC, DMAP, toluene, $72^{\circ} \mathrm{C}$

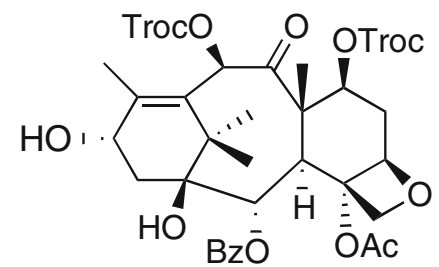

2. APTS, $\mathrm{MeOH}, 33 \%$ (2 steps)

3. $\mathrm{Zn}, \mathrm{AcOH}, \mathrm{AcOEt}, 30^{\circ} \mathrm{C}$ (ref. 9)<smiles>CC(=O)O[C@H](N)[C@@H](N)c1ccccc1</smiles>

Taxotere ${ }^{\circledR}$

Scheme 15. Hemisynthesis of taxotere ${ }^{\circledR}$. 
ester moieties found respectively in $\mathbf{3}$ and $\mathbf{4}$ were thus enantio- and diastereomerically prepared using this method. The Ddap, Pser, Ddil, Ile and Gser amino acid residues were then assembled using iterative DEPCmediated coupling reactions which readily provided the natural gymnangiamide. Moreover, this efficient synthesis allowed a stereochemical reassignment at the $\mathrm{C}^{34}$ stereocenter leading to a stereochemical revision of the natural product. ${ }^{48}$

\subsection{Synthesis of symbioramide}

A total synthesis of symbioramide, ${ }^{49}$ a naturally occuring bioactive ceramide, has been completed $^{50}$ using a convergent route that involved the dynamic kinetic resolution of an $\alpha$-amino $\beta$-ketoester through rutheniumSYNPHOS-catalysed hydrogenation and efficient stereoselective reduction of a $\alpha$-keto- $\beta$-yne ester (scheme 14). Thus, $\alpha$-amino $\beta$-hydroxyester 9 was readily obtained in a high enantio- and diastereoselective fashion from the corresponding $\beta$-ketoester $\mathbf{8}$ using $\left[\mathrm{Ru}((R)-\mathrm{SYNPHOS}) \mathrm{Br}_{2}\right]$ complex in the hydrogenation step, and subsequent reduction of the ester function followed by acetonide formation provided $\mathbf{1 0}$. On the other hand, carboxylic acid $\mathbf{1 3}$ was prepared from $\alpha$-keto- $\beta, \gamma$-acetylenic ester 11 through $(S)$-alpine borane reduction of the ketone function followed by stereoselective $\mathrm{LiAlH}_{4}$ reduction of the resulting propargylic alcohol. Coupling of compounds $\mathbf{1 0}$ and 13 proceeded cleanly using HATU/DIPEA, and global deprotection of the hydroxy functions then delivered symbioramide.

\subsection{Hemisynthesis of taxotere ${ }^{\circledR}$}

Furthermore, we achieved the hemisynthesis of taxotere ${ }^{\mathrm{R}},{ }^{51}$ an analogue of taxol ${ }^{\circledR}, 52$ both remarkable broad spectrum cancer therapeutic agents. ${ }^{53}$ To this end, dynamic kinetic resolution of $\alpha$-chloro $\beta$-ketoester 14 using the $(R)$-DIFLUORPHOS ligand allowed a highly enantio- and diastereoselective access to the anti protected phenylisoserine side chain $\mathbf{1 8}$ of taxotere ${ }^{\circledR}$ through formation of the enantiomerically enriched $\alpha$-chloro $\beta$-hydroxy ester $\mathbf{1 5}$, followed by conversion into the corresponding epoxide $\mathbf{1 6}$ which was regioand stereoselectively cleaved to afford $\mathbf{1 7}$ (scheme 15). Oxazolidine formation and hydrolysis of the ester function then provided the corresponding carboxylic acid $\mathbf{1 8}$ which was used for the esterification of the 7,10-bistrichloroethoxycarbonyl derivative of 10-desacetyl

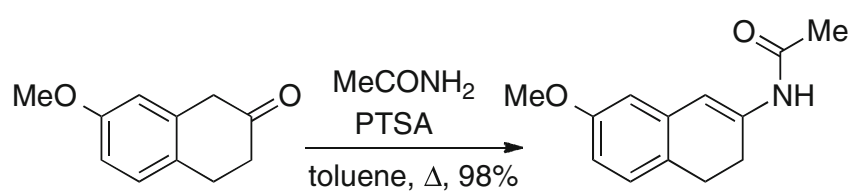

20

21<smiles>COc1ccc2c(c1)C[C@@H](NC(C)=O)CC2</smiles>

$22,95 \%$ ee

$[\mathrm{Ru}]=\left[\{\mathrm{RuCl}((R)-\mathrm{SYNPHOS})\}_{2}(\mu-\mathrm{Cl})_{3}\right]^{-}\left[\mathrm{NH}_{2} \mathrm{Me}_{2}\right]^{+}$

i. $(\mathrm{COCl})_{2}$, pyridine, $\mathrm{THF}, 0^{\circ} \mathrm{C}$
ii. propylene glycol, $0^{\circ} \mathrm{C}$ to rt
iii. $\mathrm{NaHCO}_{3}, 66 \%$

$\stackrel{\text { ref } 56 e}{\longrightarrow}$<smiles>COc1ccc2c(c1)C[C@@H](N)CC2</smiles>

23

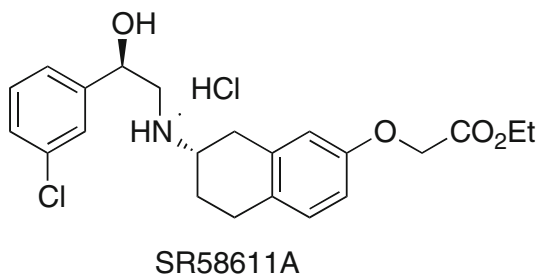

Scheme 16. Synthesis of SR58611A. 
baccatin III 19 under previously reported conditions. ${ }^{54}$ Subsequent cleavage of the oxazolidine moiety and deprotection of the 2,2,2-trichloroethoxycarbonyl (Troc) groups ${ }^{55}$ then afforded taxotere ${ }^{\mathrm{R}}$.

\subsection{Synthesis of SR58611A}

SR58611A ${ }^{56}$ is a potent and selective $\beta_{3}$-adrenergic receptor agonist for the treatment of various diseases including obesity, type 2 diabetes and depression. We reported a practical synthesis ${ }^{57}$ of this compound involving the Ru-SYNPHOS-mediated asymmetric hydrogenation of the trisubstituted $N$-acetyl enamide 21 prepared from the corresponding 2-tetralone (scheme 16). The reduction was carried out under 40 bar of hydrogen pressure in methanol in the presence of $1 \mathrm{~mol} \%$ of $\left[\{\operatorname{RuCl}((R)-\mathrm{SYNPHOS})\}_{2}(\mu-\mathrm{Cl})_{3}\right]-$ $\left[\mathrm{NH}_{2} \mathrm{Me}_{2}\right]$, and delivered the hydrogenated compound in good yield and $95 \%$ ee. Deprotection of the amine was performed under mild conditions ${ }^{58}$ and the resulting aminotetralin $\mathbf{2 2}$ was reacted with $(R)$-chlorostyrene in refluxing DMSO to afford enantiomerically pure SR58611A after crystallization of the corresponding hydrochloride salt. ${ }^{56 e}$

\section{Conclusion}

Some recent applications of DIFLUORPHOS, SYNPHOS and SYNPHOS analogue ligands have been described. These atropisomeric diphosphanes exhibiting complementary stereoelectronic properties proved their efficiency in both $\mathrm{C}-\mathrm{H}$ and $\mathrm{C}-\mathrm{C}$ bond-forming processes. Thus, asymmetric hydrogenation of trisubstituted enamides, quinoline, quinoxaline and isoquinoline derivatives catalysed by ruthenium or iridium complexes bearing those ligands provided in high yields and good to excellent selectivity the corresponding enantiomerically enriched oxygen and nitrogen-containing scaffolds which are relevant targets in the pharmaceutical industry. Carbon-carbon bond-forming processes were addressed as well and studies of asymmetric conjugate 1,4-addition of arylboronic acids to activated alkenes, asymmetric intramolecular Pauson-Khand reaction and cycloisomerization of $\mathrm{N}$-tethered 1,6-enynes demonstrated the high performance of DIFLUORPHOS, SYNPHOS and SYNPHOS analogues. Finally, application of these $\mathrm{C}-\mathrm{H}$ and $\mathrm{C}-\mathrm{C}$ bond-forming processes to the synthesis of several biologically relevant compounds including gymnangiamide, symbioramide, taxotere and SR58611A is also reported.

\section{Acknowledgements}

We thank all the co-workers who have been involved in these projects and whose names appear in the references.

\section{References}

1. Anastas P N and Kirchhoff M M 2002 Acc. Chem. Res. 35686

2. (a) Noyori R 2002 Angew. Chem. Int. Ed. 41 2008; (b) Genet J P 2003 Acc. Chem. Res. 36 908; (c) de Vries J G and Elsevier C J 2006 Handbook of homogeneous hydrogenation (Weinheim, Germany: Wiley-VCH); (d) Shang G, Li W and Zhang X 2010 In Catalytic asymmetric synthesis (3rd ed.) I Ojima (ed) (New York: John Wiley \& Sons) pp. 343-436; (e) Ager D J, de Vries A H M and de Vries J G 2012 Chem. Soc. Rev. 413340

3. (a) McCarthy M and Guiry P J 2001 Tetrahedron $\mathbf{5 7}$ 3809; (b) Tang W and Zhang X 2003 Chem. Rev. 103 3029

4. (a) Duprat de Paule S, Champion N, RatovelomananaVidal V, Genet J P, Dellis P Synkem, FP 0,112, 499; 2001, PCT FR02/03146; (b) Duprat de Paule S, Champion N, Ratovelomanana-Vidal V, Genet J P, Dellis P, Synkem 2003 WO 03029259; (c) Duprat de Paule S, Jeulin S, Ratovelomanana-Vidal V, Genet J P, Champion N and Dellis P 2003 Tetrahedron Lett. 44 823; (d) Duprat de Paule S, Jeulin S, RatovelomananaVidal V, Genet J P, Champion N and Dellis P 2003 Eur. J. Org. Chem. 1931; (e) Duprat de Paule S, Jeulin S, Ratovelomanana-Vidal V, Genet J P, Champion N, Deschaux G and Dellis P 2003 Org. Process Res. Dev. 7 399; (f) See also Pai C C, Li Y M, Zhou Z Y and Chan A S C 2002 Tetrahedron Lett. $\mathbf{4 3} 2789$

5. (a) Jeulin S, Duprat de Paule S, Ratovelomanana-Vidal V, Genet J P, Champion N and Dellis P 2004 Angew. Chem. Int. Ed. 43 320; (b) Jeulin S, Duprat de Paule S, Ratovelomanana-Vidal V, Genet J P, Champion N and Dellis P 2004 Proc. Natl. Acad. Sci. USA 101 5799; (c) Genet J.-P, Ayad T, and Ratovelomanana-Vidal V 2014 Chem. Rev. DOI:cr-2013-003243

6. Hatzenbuhler N T, Baudy R, Evrard D A, Failli A, Harrison B L, Lenicek S, Mewshaw R E, Saab A, Shah U, Sze J, Zhang M, Zhou D, Chlenov M, Kagan M, Golembieski J, Hornby G, Lai M, Smith D L, Sullivan K M, Schechter L E and Andree T H 2008 J. Med. Chem 516980

7. (a) Dupau P, Bruneau C and Dixneuf P H 1999 Tetrahedron: Asymmetry 10 3467; (b) Dupau P, Le Gendre P, Bruneau C and Dixneuf P H 1999 Synlett 11 1832; (c) Renaud J L, Dupau P, Hay A E, Guingouain M, Dixneuf P H and Bruneau C 2003 Adv. Synth. Catal. 345 230; (d) Pave G, Usse-Versluys S, Viaud-Massuard M C and Guillaumet G 2003 Org. Lett. 23 4253; (e) Holmberg P, Tedenborg L, Rosqvist S and Johansson A M 2005 Bioorg. Med. Chem. Lett. 15 747; (f) Holmberg P, Sohn D, Leideborg R, Caldirola P, Zlatoidsky P, Sverker H, Mohell N, Rosqvist S, Nordvall G, Johansson A M and Johansson R 2004 J. Med. Chem. 47 3927; (g) Zhou D, Hatzenbuhler N T, Gross J L, Harrison B L, Evrard D A, 
Chlenov M, Golembiesky J, Hornby G, Schechter L E, Smith D L, Andree T H and Stack G P 2007 Bioorg. Med. Chem. Lett. 17 3117; (h) Usse-Versluys S, Pave G, Guillaumet G and Viaud-Massuard M C 2001 Tetrahedron: Asymmetry 12 1689; (i) Fuganti C and Sacchetti A 2010 J. Mol. Catal. B: Enzym. 66276

8. Wu Z, Ayad T and Ratovelomanana-Vidal V 2010 Org. Lett. 133782

9. (a) Wang D S, Chen Q A, Lu S M and Zhou Y G 2012 Chem. Rev 1122557 and references cited herein; (b) Fleury-Brégeot N, De La Fuente V, Castillon S and Claver C 2010 Chem. Cat. Chem. 2 1346; (c) Kuwano R 2008 Heterocycles 76 909; (d) Glorius F. 2005 Org. Biomol. Chem. 3 4171; (d) Bartoszewicz A, Ahlsten N and Martin-Matute B 2013 Chem. Eur. J. 197274

10. (a) Wang W B, Lu S M, Yang P Y, Han X W and Zhou Y G 2003 J. Am. Chem. Soc. 125 10536; (b) Lu S M, Wang Y Q, Han X W and Zhou Y G 2006 Angew. Chem. Int. Ed. 452260

11. (a) Xu L, Lam K H, Ji J, Wu J, Fan Q H, Lo W H and Chan A S C 2005 Chem. Commun. 1390; (b) Wu J and Chan A S C 2006 Acc. Chem. Res. 39711

12. Qui L, Kwong F Y, Wu J, Lam W H, Chan S, Yu W Y, Li Y M, Guo R, Zhou Z and Chan A S C 2006 J. Am. Chem. Soc. 1285955

13. (a) Deport C, Buchotte M, Abecassis K, Tadaoka H, Ayad T, Ohshima T, Genet J P, Mashima K, Ratovelomanana-Vidal V 2007 Synlett 2243; (b) Tang W, Sun Y, Wang T, Fan Q, Lam K H and Chan A S C 2010 Org. Biomol. Chem. 83464

14. Wang X B and Zhou Y G 2008 J. Org. Chem. 735640

15. Gou F R, Li W, Zhang X and Liang Y M $2010 A d v$. Synth. Catal. 3522441

16. Zhang D Y, Wang D S, Wang M C, Yu C B, Gao K and Zhou Y G 2011 Synthesis 172796

17. Zhang D Y, Yu C B, Wang M C, Gao and Zhou Y G 2012 Tetrahedron Lett. 532555

18. Yamagata T, Tadaoka H, Nagata M, Hirao T, Kataoka Y, Ratovelomanana-Vidal V, Genet J P and Mashima K 2006 Organometallics 252505

19. Tadaoka H, Cartigny D, Nagano T, Gosavi T, Ayad T, Genet J P, Ohshima T, Ratovelomanana-Vidal V and Mashima K 2009 Chem. Eur. J. 159990

20. (a) Chang G, Didiuk M T, Finneman J Y, Garigipati R S, Kelley R M, Perry D A, Ruggeri R B and Bechle B M 2004 WO 2004085401; (b) Gluchowski C 2004 EP 0422878A1; (c) Torisu K, Kobayashi K, Iwahashi M, Nakai Y, Onoda T, Nagase T, Sugimoto I, Okada Y, Matsumoto T, Nanbu F, Ohuchida S, Nakai H and Toda M 2004 Bioorg. Med. Chem. 12 5361; (d) Kuhl A, Kolkhof P, Telan L, Peters J G, Lustig K, Kast R, Muenter K, Stasch J P and Tinel H 2005 WO 2005028451; (e) Sikorski J A 2006 J. Med. Chem. 49 1; (f) Abraham C J, Paull D H, Scerba M T, Grebinski J W and Lectka T 2006 J. Am. Chem. Soc. 128 13370; (g) Eary C T, Jones Z S, Groneberg R D, Burgess L E, Mareska D A, Drew M D, Blake J F, Laird E R, Balachari D, O'Sullivan D, Allen A and Marsh V 2007 Bioorg. Med. Chem. Lett. 172608

21. Murata S, Sugimoto T and Matsuura S 1987 Heterocycles 26763
22. (a) Bianchini S, Barbaro P, Scapacci G, Farnetti E and Graziani M 1998 Organometallics 17 3308; (b) Bianchini C, Barbaro P and Scapacci G 2001 J. Organomet. Chem. 621 26; (c) Henschke J P, Burk M J, Malan C G, Herzberg D, Peterson J A, Wildsmith A J, Cobley C J and Casy G 2003 Adv. Synth. Catal. 345300

23. Qiu L, Kwong F Y, Wu J, Lam W H, Chan S, Yu W Y, Li Y M, Guo R, Zhou Z and Chan A S C 2006 J. Am. Chem. Soc $\mathbf{1 2 8} 5955$

24. Tang W, Xu L, Fan Q H, Wang J, Fan B, Zhou Z, Lam K $\mathrm{H}$ and Chan A S C 2009 Angew. Chem. Int. Ed. 489135

25. Mršić N, Jerphagnon T, Minnaard A J, Feringa B L and de Vries J G 2009 Adv. Synth. Catal. 3512549

26. Wang D S and Zhou Y G 2010 Tetrahedron Lett. 513014

27. (a) Cartigny D, Nagano T, Ayad T, Genet J P, Ohshima T, Mashima K and Ratovelomanana-Vidal V 2010 Adv. Synth. Catal. 352 1886; (b) Cartigny D, Berhal F, Nagano T, Phansavath P, Ayad T, Genet J P, Ohshima T, Mashima K and Ratovelomanana-Vidal V $2012 \mathrm{~J}$. Org. Chem. 774544

28. Nagano T, Iimuro A, Schwenk R, Ohshima T, Kita Y, Togni A and Mashima K 2012 Chem. Eur. J. 1811578

29. (a) Phillipson J D, Roberts M F and Zenk M H 1985 The Chemistry and biology of isoquinoline alkaloids (Berlin: Springer); (b) Jack D and Williams R 2002 Chem. Rev. 102 1669; (c) Bentley K W 2006 Nat. Prod. Rep. 23444

30. For selected examples, see: (a) Murahashi S I, Watanabe S and Shiota T 1994 J. Chem. Soc. Chem. Commun. 725; (b) Taniyama D, Hasegawa M, and Tomioka K 1999 Tetrahedron: Asymmetry 10 221; (c) Ooi T, Takeuchi M and Maruoka K 2001 Synthesis 1716; (d) Ito K, Akashi S, Saito B and Katsuki T 2003 Synlett 1809; (e) Taylor M S and Jacobsen E N 2004 J. Am. Chem. Soc. 126 10558; (f) Seayad J, Seayad A M and List B 2006 J. Am. Chem. Soc. 128 1086; (g) Sasamoto N, Dubs C, Hamashima Y and Sodeoka M 2006 J. Am. Chem. Soc. 128 14010; (h) Dubs C, Hamashima Y, Sasamoto N, Seidel T M, Suzuki S, Hashizume D and Sodeoka M 2008 J. Org. Chem. 73 5859; (i) Wang S, Onaran M B and Seto C T 2010 Org. Lett. 122690

31. Willoughby C A and Buchwald S L 1994 J. Am. Chem. Soc. 1168952

32. Uematsu N, Fujii A, Hashiguchi S, Ikariya T and Noyori R 1996 J. Am. Chem. Soc. 1184916

33. For asymmetric hydrogenation: (a) Morimoto $\mathrm{T}$, Nakajima N and Achiwa K 1995 Tetrahedron: Asymmetry 6 75; (b) Morimoto T and Achiwa K 1995 Tetrahedron: Asymmetry 6 2661; (c) Morimoto T, Suzuki N and Achiwa K 1998 Tetrahedron: Asymmetry 9 183; (d) Zhu G and Zhang X 1998 Tetrahedron: Asymmetry 92415 ; (e) Cobley C J and Henschke J P 2003 Adv. Synth. Catal. 345 195; (f) Guiu E, Claver C, Benet-Buchholz J and Castillon S 2004 Tetrahedron: Asymmetry 15 3365; (g) Jackson M and Lennon I C 2007 Tetrahedron Lett. 48 1831; (h) Li C and Xiao J 2008 J. Am. Chem. Soc. 130 13208; (i) Yan P C, Xie J H, Hou G H, Wang L X and Zhou Q L 2009 Adv. Synth. Catal. 351 3243; (j) Lu S M, Wang Y G, Han X W and Zhou Y G 2009 Angew. Chem. Int. Ed. 45 2260; (k) Chang M, Li W and Zhang X 2011 Angew. Chem. Int. Ed. 50 10679; (1) Xie J H, Yan P C, Zhang Q Q, Yuan K X and Zhou Q L 2012 ACS Catal. 2 561; For asymmetric transfer hydrogenation, see: (m) Vedejs E, Trapencieris P and Suna E 1999 J. Org. Chem. 
64 6724; (n) Mao J and Baker D C 1999 Org. Lett. 1 841; (o) Williams G D, Pike R A, Wade C E and Wills M 2003 Org. Lett. 5 4227; (p) Williams G D, Wade C E and Wills M 2005 Chem. Commun. 4735; (q) Szawkalo J and Czarnocki Z 2005 Monatsh. Chem. 136 1619; (r) Wu J, Wang F, Ma Y, Cui X, Cun L, Zhu J, Deng J and Yu B 2006 Chem. Commun. 1766; (s) Canivet J and Süss-Fink G 2007 Green Chem. 9 391; (t) Matharu D S, Martins J E D and Wills M 2008 Chem. Asian J. 3 1374; (u) Martins J E D, Clarkson G J and Wills M 2009 Org. Lett. 11 847; (v) Evanno L, Ormala J and Pihko P M 2009 Chem. Eur. J. 15 12963; (w) Martins J E D, Redondo M A C and Wills M 2010 Tetrahedron: Asymmetry 212258

34. Berhal F, Wu Z, Zhang Z, Ayad T and RatovelomananaVidal V 2012 Org. Lett. 143308

35. Iimuro A, Yamaji K, Kandula S, Nagano T, Kita Y and Mashima K 2013 Angew. Chem. Int. Ed. 52, 2046

36. Reviews: (a) Trost B M and Krische M J 1998 Synlett 1; (b) Chianese A R, Lee S J and Gagne M R 2007 Angew. Chem. Int. Ed. 46 4042; (c) Michelet V, Toullec P Y, Genet J P 2008 Angew. Chem. Int. Ed. 47 4268; (d) Fürstner A 2009 Chem. Soc. Rev. 38 3208. (e) Soriano E and Marco-Contelles J 2009 Acc. Chem. Res. 42 1026; (f) Pradal A, Toullec P Y and Michelet V 2011 Synthesis 1501; (g) Aubert C, Fensterbank L, Garcia P, Malacria M and Simonneau A 2011 Chem. Rev. 111 1954; (h) Marinetti A, Jullien H and Voituriez A 2012 Chem. Soc. Rev. 414884

37. Jackowski O, Wang J, Xie X, Ayad T, Zhang Z and Ratovelomanana-Vidal V 2012 Org. Lett. 144006

38. Takaya Y, Osawara M, Hayashi T, Sakai M and Miyaura N 1998 J. Am. Chem. Soc. 1205579

39. Reviews: (a) Hayashi T and Yamasaki K 2003 Chem. Rev. 103 2829; (b) Fagnou K and Lautens, M 2003 Chem. Rev. 103 169; (c) Hayashi T 2004 Pure Appl. Chem. 76 465; (d) Edwards H J, Hargrave J D, Penrose S D and Frost, C G 2010 Chem. Soc. Rev. 39 2093; (e) Miyaura M 2008 Bull. Chem. Soc. Jpn. 81 1535; (f) Harutyunyan S R, den Hartog T, Geurts K, Minnaard A J and Feringa B L 2008 Chem. Rev. 108 2824

40. Reviews: (a) Shintani R and Hayashi T 2009 Aldrichim. Acta 42 31; (b) Defieber C, Grützmacher H and Carreira E 2008 Angew. Chem. Int. Ed. 474482

41. (a) Korenaga T, Osaki R, Maenishi R and Sakai T 2009 Org. Lett. 11 2325; (b) Korenaga T, Maenishi R, Hayashi K and Sakai T 2010 Adv. Synth. Catal. 3523247

42. (a) Shintani R, Ueyama K, Yamada I and Hayashi T 2004 Org. Lett. 6 3425; (b) Shintani R, Duan W L, Nagano T, Okada A and Hayashi T 2005 Angew. Chem., Int. Ed. 44 4611; (c) Shintani R, Duan W L and Hayashi T 2006 J. Am. Chem. Soc. 128 5628; (d) Piras E, Läng F, Rüegger H, Stein D, Wörle M and Grützmacher H 2006 Chem. Eur. J. 12 5849; (e) Nishikata T, Yamamoto Y and Miyaura N 2007 Chem. Lett. 36 1442; (f) Duan W L, Iwamura H, Shintani R and Hayashi T 2007 J. Am. Chem. Soc. 129 2130; (g) Duan W L, Shintani R and Hayashi T 2007 Tetrahedron 63 8529; (h) Luo Y and Carnell A J 2010 Angew. Chem. Int. Ed. 49 2750; (i) Thaler T, Guo L N, Steib A K, Raducan M, Karaghiosoff K, Mayer P and Knochel P 2011 Org. Lett. 133182
43. Khand I U, Knox G R, Pauson P L and Watts W E 1971 J. Chem. Soc. Chem. Commun. 36

44. Reviews: (a) Frühauf H W 1997 Chem. Rev. 97 523; (b) Geis O and Schmalz H G 1998 Angew. Chem. Int. Ed. 37 911; (c) Brummond K M and Kent J L 2000 Tetrahedron 56 3263; (d) Gibson S E and Stevenazzi A 2003 Angew. Chem. Int. Ed. 42 1800; (e) BlancoUrgoiti J, Anorbe L, Perez-Serrano L, Dominguez G and Perez-Castells J 2004 Chem. Soc. Rev. 33 32

45. (a) Ward R S 1990 Chem. Soc. Rev. 19 1; (b) Willis M C 1999 J. Chem. Soc., Perkin Trans. 1, 1765

46. Kim D E, Lee B H, Rajagopalasarma M, Genet J P, Ratovelomanana-Vidal V and Jeong N 2008 Adv. Synth. Catal. 3502695

47. Milanowski D J, Gustafson K R, Rashid M A, Pannell L K, McMahon J B and Boyd M R 2004 J. Org. Chem. 69 3036

48. Tone H, Buchotte M, Mordant C, Guittet E, Ayad T and Ratovelomanana-Vidal V 2009 Org. Lett. 111995

49. (a) Kobayashi J, Ishibashi M, Nakamura H, Hirata Y, Yamasu T, Sasaki T and Ohizumi Y 1988 Experientia 44 800; (b) Kobayashi J 1989 J. Nat. Prod. 52 225

50. Prévost S, Ayad T, Phansavath P and RatovelomananaVidal. V 2011 Adv. Synth. Catal. 3533213

51. (a) Colin M, Guénard D, Guéritte-Voegelein F and Potier P (Rhône-Poulenc Santé) 20 Jan 1988 Eur. Pat. Appl. EP 253738 (Cl. C07D305/14), 17 Jul 1986 FR Appl. 86/10,400, 1988 Chem. Abstr. 109 22762w; (b) Mangatal L, Adeline M T, Guénard D, GuéritteVoegelein F and Potier P 1989 Tetrahedron 454177

52. Wani M C, Taylor H L, Wall M E, Coggon P and McPhail A T 1971 J. Am. Chem. Soc. 932325

53. Prévost S, Gauthier S, Mordant C, Touati A R, Lesot P, Savignac P, Ayad T, Phansavath P, RatovelomananaVidal V and Genêt J P 2010 Tetrahedron: Asymmetry 21 1436

54. Denis J N, Kanazawa A M and Greene A E 1994 Tetrahedron Lett. 35105

55. Didier E, Fouque E, Taillepied I and Commerçon A 1994 Tetrahedron Lett. 35234

56. (a) Nakajima Y, Washizuka K, Sakurai M, Matsui S, Imamura E, Ueshima K, Yamamoto T, Yamamoto $\mathrm{N}$, Ishikawa $\mathrm{H}$, Nakano $\mathrm{K}$, Unami $\mathrm{N}$, Hamada K, Matsumura Y, Takamura F and Hattori K 2008 J. Med. Chem. 51 1925; (b) Imanishi M, Nakajima Y, Tomishima Y, Hamashima H, Washizuka K, Sakurai M, Matsui S, Imamura E, Ueshima K, Yamamoto T, Yamamoto N, Ishikawa H, Nakano K, Unami N, Hamada K, Matsumura Y, Takamura F and Hattori K 2008 J. Med. Chem. 51 4804; (c) Sawa M and Harada H 2006 Curr. Med. Chem. 13 25; (d) Devocelle M, Mortreux M, Agbossou F and Dormoy J P 1999 Tetrahedron Lett. 40 4551; (e) Cecchil R, Crocil T, Boigegrainz R, Boveril S, Baronil M, Boccardil G, Guimbardz J P and Guzzil U 1994 Eur. J. Med. Chem. 29259

57. Pautigny C, Debouit C, Vayron P, Ayad T and Ratovelomanana-Vidal V 2010 Tetrahedron: Asymmetry 211382

58. Koenig S G, Vandenbossche C P, Zhao H, Mousaw P, Singh S P and Bakale R P 2009 Org. Lett. 11433 